DOI: 10.22616/REEP.2021.14.011

\title{
Evaluation of IT Companies as Learning Organizations from the Programmers' Perspective
}

\author{
Edgars Katans ${ }^{1} \mathrm{Mg}$. paed.; (DIrena Katane ${ }^{2}$ Dr. paed. \\ IT company "Autentica”, Latvia ${ }^{1}$; Latvia University of Life Sciences and Technologies, Latvia ${ }^{2}$ \\ edgars.katans@inbox.lv'; irena.katane@inbox.lv²
}

\begin{abstract}
The modern social science faces a new synergetic and social-ecological paradigm and the respective approaches in research activity. The synergetic approach allows for the investigation of a learning IT company as a "living" system, a synergic organization notable for its teamwork and team learning to ensure the introduction of innovations in the company and, along with that, a sustainable development and competitiveness of the company in a constantly changing environment. In its turn, the social-ecological approach allows a researcher to focus his attention on a continuous professional development of an individual programmer or a team of programmers by mutual cooperation and interaction with the whole IT company representing the environment of their professional activity and continuous learning. A learning organization has certain traits or indicators, which can be used for the evaluation of IT companies. The authors have developed a methodology for the evaluation of learning IT companies, which has been approved during the experimental research: a case study. 102 programmers working for various Latvian IT companies participated in the study. The aim of the study: to analyse the IT companies where the research participants work, evaluating them as learning organizations, as well as to assess the informational awareness and knowledge of the programmers about the continuous professional development and career growth possibilities at the respective companies. Among the 19 indicators (traits) of evaluation of a learning organization, the following three traits are the most typical ones for the IT companies where the research participants are working: (1) friendly atmosphere and mutual support within a company, cooperation when working as a team, sharing their knowledge, skills, competencies and experience while performing their work duties; (2) a company is trying to ensure its sustainable development and competitive ability; (3) self-education and continuous learning of a company to improve its activity and to diversify the variety of the target groups along with a continuous improvement of its products and services.
\end{abstract}

Keywords: evaluation, IT company, learning organization, programmers' continuous professional development.

\section{Introduction}

Nowadays the synergetic approach becomes topical in the social sciences, highlighting the role of synergy within an organization (Dhurup,Surujlal, Kabongo, 2016; Haken, 1985; Pakeltienė, Ragauskaite, 2017; Tarba et al., 2019; Wang et al., 2020). The synergetic approach allows for the validation of an IT company as a synergic organization, which is able to cooperate, to change its internal structure according to certain goals and objectives of the activity, to be creative in the introduction of innovations to ensure its development and sustainability. The synergetic approach allows for the examination and evaluation of any organization, any IT company as a "living" system, which is able of self-organisation, self-development with the aim to ensure its viability in modern changing environment, as well as its sustainability in the long run (Bryanskiy, Pozharskiy, 2002; Haken, 1985; Katane, 2005; Katane, Katans, 2018; Prigozine, 1980; Shevlokov, 2016). The synergy in a synergic organization becomes actual not only in the common goal-based professional activity, which implies a well-coordinated teamwork, but also in common learning. A synergic organization as such is a learning organization that is capable and able to analyse the surrounding environment, the changes happening in this environment, as well as to assess its advantages and drawbacks.

Whereas, based on the ecological approach in the social sciences (Bronfenbrenner, 1979; Katane, 2005; Katane, Kristovska, Katans, 2014; Mas, Gomez, 2021; Säljö, 2020; Steiner, 2008), an important declaration has been made that both the professional development of the whole synergic learning organization and of its specialist is happening in interaction with the surrounding environment. The environment of professional activity plays a big part in the professional development of a specialist (Iriste, 2018; Katane, 2007). This main point can be applicable also for the programmers, whose 
professional development happens in cooperation with the IT company (Katane, Katans, 2016) he works for. On the one hand, the continuous professional development of programmers not only ensures their competitiveness but also ensures the competitiveness and sustainability of the whole IT company. On the other hand, many IT companies have become the learning organizations, thus ensuring the possibility of continuous professional development of their specialists within the company's environment (Baranova, 2012; Chen, 2005; González-Torres et al., 2016; Bologa, Lupu, 2014; Katane, Katans, 2018; Katans, 2019; Lipowsky, 2017; Shujahat et al., 2019).

Nowadays, to ensure its sustainable development and competitive ability in the constantly changing conditions (environment), increasingly companies become learning organizations with the characteristic management of knowledge and competencies. The sprouts of a learning organization concept can be found at the end of the $20^{\text {th }}$ century, but it is still developing and it is also highly topical nowadays (Anjaria, 2020; Antunes, Pinheiro, 2020; Barão et al., 2017; Bootz et al., 2019; Judrups, 2017; Serrat, 2017; Yang et al., 2020).

A number of basic insights characterising the learning organization was actualised already at the end of the $20^{\text {th }}$ century (Garvin, 1993; Rozenholtz, 1989; Senge, 1990). New and wide thinking models have been created within a learning organization, which imply a free striving of a team in pursuing a goal to be achieved thanks to team learning, which is consistent with the basic principles of a synergic organization actualised nowadays. Within these organizations, people as personalities and as professionals are constantly enlarging their capacity, the specialists are learning from one another. A learning organization are able to create, acquire and transfer knowledge and to transform their activities based on the new knowledge and comprehension. The organizational learning has a transformative influence as it helps the organization: (1) to find and correct mistakes in its activities, thus maintaining the policy of its activities and achieving the set goals; (2) to change by modifying the existing norms, working strategies, directions and aims.

The cooperation in efficient learning organizations is connected with a continuous professional development throughout the career and learning from personal experience and the experience of other people. Nowadays, as a part of knowledge and competence management, many learning organizations are offering their specialists ample possibilities of formal and non-formal continuous in-company professional development (Argote, Hora, 2017; Bootz et al., 2019; Huang, Zhang, Huang, 2020; Katane, Katans, 2018; Kianto, Sáenz, Aramburu, 2017).

Scientists and practitioners have conceptualised the essence of professional development, where equal importance is attributed to both formal and non-formal continuous learning for professional development, including well-structured, specially organised in-company training courses, co-education or team learning, experience exchange, including improvised non-formal discussions with colleagues, thematic practical conferences and/or seminars, etc. (Halpin, Curtis, Halpin, 2015; Kennedy, 2016; Masoumi, Hatami, Pourkaremi, 2018; Mitina, 2004).

Working and learning by cooperating in a team is a characteristic feature of a learning organization, which can be referred to many IT companies, especially those where the programmers are working and cooperating within the Agile methodology. The process of continuous self-development of a team, experience-based training and close ties with the client is an integral part of the Agile methodology (Drury-Grogan, Conboy, Acton, 2017; Katans, 2019; Lipowsky, Schmidt, 2016; Lipowsky, 2017; St-Germain et al., 2020).

As the experience shows, many learning IT companies offer multiform mentoring aimed at promoting the continuous professional development of programmers. The multiformity of mentoring in various enterprises and institutions has been validated and explored by a number of authors (Bendickson, Madden, Matherne, 2020; Gay, 1995; Cranwell-Ward, Bossons, Gover 2004; Kačkere, Odina, Rieksta, 2005; Katans, 2019; Konstantinova, Rivža, 2007; Konstantinova, 2008; Krūzmētra, 2006). The experience suggests that to support the career growth of programmers, many IT companies have developed, approved and implemented the methodology for the evaluation of professional development of programmers during career talks. It allows for the understanding of problem areas that should be solved within the framework of knowledge and competence management of the IT company, including the promotion of each programmer's professional development. 
At the same time, it is important for each programmer to know what are the possibilities of his/her professional development and career growth within the learning IT company. This information allows to self-manage his/her continuous learning and career at the company. Information awareness and knowledge about the possibilities of continuous professional development offered by the IT company, including special continuous professional training courses for programmers, forms of mentoring performed within the framework of knowledge and competence management, become a basis for professional self-development of programmers in interaction with the IT company as the environment of professional activity and continuous learning.

The aim of the study: To analyse the IT companies where the research participants work, evaluating them as learning organizations, as well as to assess the informational awareness and knowledge of the programmers about the continuous professional development and career growth possibilities at the respective companies.

\section{Methodology}

The research occurred in 2019 - 2020 and by definition it is a case study. In the research 102 programmers from various Latvian IT companies voluntary participated. The information about the research participants is summarised in Table 1, showing the age of the participants, the total work experience in years and the length of employment in IT companies.

Table 1

Descriptive information about the research participants $(n=102)$

\begin{tabular}{|l|l|l|l|l|l|l|l|}
\hline $\mathbf{N}$ & \multicolumn{1}{|c|}{ Indicators } & \multicolumn{1}{|c|}{ Min } & \multicolumn{1}{|c|}{ Max } & \multicolumn{1}{c|}{ A } & \multicolumn{1}{c|}{ Me } & \multicolumn{1}{c|}{ Mo } & \multicolumn{1}{c|}{$\overline{\boldsymbol{x}}$} \\
\hline 1 & Age (years) & 20 & 50 & 30 & 28 & 23 & 29.2 \\
\hline 2 & Work experience in total (years) & 2 & 25 & 23 & 6 & 4 & 8,1 \\
\hline 3 & $\begin{array}{l}\text { Programming work experience in IT companies } \\
\text { (full years) }\end{array}$ & $\begin{array}{l}0 \\
(\ldots<1)\end{array}$ & 25 & 25 & 4.5 & 4 & 7.2 \\
\hline
\end{tabular}

The research participants represented the IT companies that can be characterised by two important criteria:

- location: 1) Latvia: Riga; 2) Latvia: near Riga; 3) Latvia: other city/town (the research participants do not work for any IT companies located abroad);

- type of company: 1) a Latvian company without representation abroad; 2) a Latvian company with a representation abroad; 3 ) a foreign company with a representative office in Latvia (the research participants do not work for any IT company that can be characterised as a foreign company without a representative office in Latvia.

Research methods: 1) methods of data collection: survey (questionnaire); 2) data processing: primary data processing for the obtaining of descriptive statistics (the number of positive responses (n), the coefficient of specific weight of positive responses, the rank sum of positive responses $\left(\sum_{R}\right)$, overall rank considering both the sum of positive responses for each indicator and the sum of the positive response rankings ( $\mathrm{R}_{\text {coeff.; } \Sigma \mathrm{R}}$ ); secondary data processing for the obtaining of the inferential statistics (Spearman's rank correlation coefficient $r_{s}$ ) by using the Spearman Rank Correlation Test (SPSS).

The questionnaire included 19 questions with the following options to answer: yes; rather yes than no; rather no than yes; no. The respondents had to choose one of the options. Entering the data in the SPSS 21.0 software, the responses were ranked from a very negative to a very positive response: "no" $=1$; "rather no than yes" $=2$; "rather yes than no" $=3$; "yes" $=4$ (the results were summarised in a table).

The evaluation indicators represented the following indicators groups: (1) learning at an IT company as a guarantee for its sustainability and competitive ability; (2) learning and continuous professional development of programmers in a learning IT company from the perspective of knowledge management; (3) mentoring at an IT company as a part of the knowledge management; (4) methods for the evaluation of professional development of programmers in IT companies and the influence over their career's self-management. 


\section{Results and Discussion}

Primary data processing for obtaining descriptive statistics. Firstly, the primary data processing was performed to obtain the descriptive statistics: 1) the number of positive responses (n) in accordance with every evaluation indicator, 2) the coefficient of specific weight of positive responses; 3 ) the rank sum $\left(\sum_{\mathrm{R}}\right)$. Ranking the results obtained, the coefficient of the specific weight of positive responses was firstly considered. If the coefficients were equal in accordance with several indicators, the secondary value used for ranking was the rank sum of positive responses $\left(\sum_{R}\right)$. Consequently, the overall rank symbol is $\mathrm{R}_{\text {coeff:; } \sum \mathrm{R}}($ Table 2).

Table 2

Evaluation of IT companies as learning organizations, as well as the possibilities of professional development and career growth within such companies from the programmers' perspective: descriptive statistics $(n=102)$

\begin{tabular}{|c|c|c|c|c|c|}
\hline \multirow[b]{2}{*}{$\mathbf{N}$} & \multirow[b]{2}{*}{ Indicators } & \multicolumn{3}{|c|}{ Positive Responses } & \multirow{2}{*}{$\mathbf{R}_{\text {coeff:; }}$} \\
\hline & & $\mathbf{n}$ & $\begin{array}{l}\text { Coeff. of } \\
\text { specific } \\
\text { weight }\end{array}$ & $\sum \mathbf{R}$ & \\
\hline 1 & $\begin{array}{l}\text { Indicator } 11 \text {. The company is characterised by a friendly atmosphere and } \\
\text { mutual support, cooperation and teamwork, sharing their knowledge, skills, } \\
\text { competencies and experience }\end{array}$ & 102 & 1.00 & 378 & 1 \\
\hline 2 & $\begin{array}{l}\text { Indicator } 1 \text {. The company tries to ensure its sustainable development and } \\
\text { competitiveness }\end{array}$ & 96 & 0.94 & 363 & 2 \\
\hline 3 & $\begin{array}{l}\text { Indicator } 14 \text {. The company is self-educating and continuously learning to } \\
\text { improve its activity and diversify the variety of target groups along with a } \\
\text { continuous improvement of its products and services }\end{array}$ & 96 & 0.93 & 339 & 3 \\
\hline 4 & $\begin{array}{l}\text { Indicator } 13 \text {. The company is flexible in reacting to the market demand and } \\
\text { the needs of existing and potential clients }\end{array}$ & 93 & 0.91 & 333 & 4 \\
\hline 5 & $\begin{array}{l}\text { Indicator 3. The company has a tradition to attend various conferences, } \\
\text { seminars and other events organised outside the company, to share the } \\
\text { acquired knowledge and experience by giving presentations and organising } \\
\text { discussions with their colleagues }\end{array}$ & 93 & 0.91 & 330 & 5 \\
\hline 6 & $\begin{array}{l}\text { Indicator } 2 \text {. The corporate culture of the company attaches great importance } \\
\text { to education and continuous professional development: it organises } \\
\text { continuous professional training courses, seminars, conferences, as well as it } \\
\text { has a tradition of sharing experience }\end{array}$ & 93 & 0.91 & 321 & 6 \\
\hline 7 & $\begin{array}{l}\text { Indicator } 15 . \text { The company's specialists know the development strategy of } \\
\text { the company, its corporate objectives and tasks to be performed in the near } \\
\text { and remote future }\end{array}$ & 90 & 0.88 & 327 & 7 \\
\hline 8 & $\begin{array}{l}\text { Indicator } 12 \text {. The company supports the proactivity of the specialists and their } \\
\text { pioneering and creative activities }\end{array}$ & 87 & 0.85 & 306 & 8 \\
\hline 9 & $\begin{array}{l}\text { Indicator 5. The company investigates the needs of the continuous } \\
\text { professional development of employees by providing flexible education and } \\
\text { career development support }\end{array}$ & 87 & 0.85 & 303 & 9 \\
\hline 10 & $\begin{array}{l}\text { Indicator } 6 \text {. The company has a well-developed mentoring system for rende- } \\
\text { ring support to programmers and ensuring their continuous professional } \\
\text { development }\end{array}$ & 87 & 0.85 & 300 & 10 \\
\hline 11 & $\begin{array}{l}\text { Indicator 19. Each programmer (respondent) is well aware of his career } \\
\text { possibilities in the respective IT company and clearly understands the tasks to } \\
\text { be performed to ensure his career growth }\end{array}$ & 81 & 0.79 & 292 & 11 \\
\hline 12 & $\begin{array}{l}\text { Indicator } 10 \text {. The company ensures mentoring of novice specialists during } \\
\text { their first year of employment }\end{array}$ & 78 & 0.76 & 279 & 12 \\
\hline
\end{tabular}




\begin{tabular}{|c|c|c|c|c|c|}
\hline \multirow[b]{2}{*}{$\mathbf{N}$} & \multirow[b]{2}{*}{ Indicators } & \multicolumn{3}{|c|}{ Positive Responses } & \multirow{2}{*}{$\begin{array}{c}\mathbf{R}_{\text {coeff:; }} \\
\sum \mathrm{R}\end{array}$} \\
\hline & & $\mathbf{n}$ & $\begin{array}{l}\text { Coeff. of } \\
\text { specific } \\
\text { weight }\end{array}$ & $\sum \mathbf{R}$ & \\
\hline 13 & $\begin{array}{l}\text { Indicator } 9 \text {. In cooperation with higher education institutions, the company } \\
\text { ensures working environment-based training, offering the professional and } \\
\text { pedagogic support of mentors for students during practice }\end{array}$ & 75 & 0.74 & 243 & 13 \\
\hline 14 & $\begin{array}{l}\text { Indicator 4. New knowledge, skills and competencies obtained during the } \\
\text { continuous professional development are immediately used, thus promoting the } \\
\text { introduction of innovations in the IT company }\end{array}$ & 72 & 0.71 & 258 & 14 \\
\hline 15 & $\begin{array}{l}\text { Indicator } 8 \text {. The company has experienced career growth mentors and experts } \\
\text { who regularly assess the professional growth of the employees }\end{array}$ & 63 & 0.62 & 222 & 15 \\
\hline 16 & $\begin{array}{l}\text { Indicator } 7 . \text { The company has experienced education mentors who hold } \\
\text { continuous professional training courses for the company's specialists }\end{array}$ & 60 & 0,59 & 216 & 16 \\
\hline 17 & $\begin{array}{l}\text { Indicator } 17 \text {. The company's specialists are well aware of the criteria for the } \\
\text { evaluation and self-evaluation of their professional development in accordance } \\
\text { with the methodology elaborated by the IT company, to define their suitability } \\
\text { to a certain position at the respective IT company they work for }\end{array}$ & 60 & 0.59 & 210 & 17 \\
\hline 18 & $\begin{array}{l}\text { Indicator } 18 . \text { The methodology of the evaluation and self-evaluation of } \\
\text { professional development (its indicators) existing at the respective respondent's } \\
\text { IT company helps the programmer in his professional self-development and } \\
\text { improvement, as well as in planning his career within the company }\end{array}$ & 54 & 0.53 & 186 & 18 \\
\hline 19 & $\begin{array}{l}\text { Indicator } 16 \text {. The IT company of the respondent has the methodology for the } \\
\text { evaluation of professional development available for all specialists, which is } \\
\text { usually used during the career talks }\end{array}$ & 48 & 0.47 & 168 & 19 \\
\hline
\end{tabular}

The obtained results testify that the highest values of positive responses were obtained according to the following indicators (Table 2):

- Indicator 11: Coefficient of specific weight: 1.00; Positive response $\sum \mathrm{R}: 378 ; \mathrm{R}_{\text {coeff: } ; \mathrm{R}: 1 \text {; }}$

- Indicator 1: Coefficient of specific weight: 0.94; Positive response $\sum_{\mathrm{R}}: 363 ; \mathrm{R}_{\text {coeff:; } \Sigma \mathrm{R}}: 2$;

- Indicator 14: Coefficient of specific weight: 1.00; Positive response $\sum \mathrm{R}: 339 ; \mathrm{R}_{\text {coeff:; } \sum \mathrm{R}: 3 .}$

The highest values of assessment refer to the evaluation of an IT company as a learning organization. The respondents gave the highest assessment of the friendly, favourable atmosphere in the IT company they are working for, as well as of the possibility to work in a team, to cooperate by sharing their knowledge, skills, competencies and experience. From the perspective of the programmers who participated in the survey, the IT companies they are working for, take care and try to ensure their sustainable development and competitiveness, as the company is self-educating or continuously learning to improve its activities and diversify the variety of target groups along with a continuous improvement of its products (usage and quality) and production process as such.

The lowest values of positive responses were obtained according to the following indicators (Table 2):

- Indicator 17: Coefficient of specific weight: 0.59; Positive response $\sum_{\mathrm{R}}: 210 ; \mathrm{R}_{\text {coeff.; }} \mathrm{R}: 17$;

- Indicator 18: Coefficient of specific weight: 0.53; Positive response $\sum \mathrm{R}: 186 ; \mathrm{R}_{\text {coeff.; }}[\mathrm{R}: 18$;

- Indicator 16: Coefficient of specific weight: 0.47; Positive response $\sum_{\mathrm{R}}: 168 ; \mathrm{R}_{\text {coeff.; }}[\mathrm{R}: 19$.

These results attest that the lowest values of assessment were obtained within the indicator group representing the information awareness of programmers in relation to the evaluation of their professional development in the IT company they work for, which affects the self-management of their professional development and career growth.

The obtained results allowed to conclude that not all IT companies represented by the respondents have the methodology elaborated and used for the evaluation of professional development of programmers. If such a methodology still exists at the IT company represented by the respondents, then only $59 \%$ of respondents know the criteria and indicators of assessment of this methodology, as there are problems with the exchange of information. Only $53 \%(n=54)$ of the respondents answered that the methodology existing in the company helps them in their professional development and improvement, as well as in planning their career 
within the company. Only 48 respondents (that is, less than half (47\%)) admit that the methodology for the evaluation of professional development and improvement, which is elaborated and introduced to all the specialists, is used at their IT companies during career talks and in the preparation for such talks.

The earlier studies in the field of the assessment of specialists' competitiveness (Iriste, 2018; Katans, Katane, Baltusite, 2020) attest that it is very important for both the specialists-to-be and for the existing specialists to know the criteria for their self-evaluation. This is attested by the transformational experiment results. During this experiment, the research participants were offered a possibility to familiarise themselves with a system of self-evaluation indicators. The obtained results allowed for the conclusion that there are critical differences between the self-evaluation before and after the experiment.

Secondary data processing for obtaining inferential (conclusive) statistics. During the next stage of data processing, all possible sets of pairs of features (indicators) have been compared (Table 3). The respondents' responses were offered in a verbal form, but they have been ranked by attributing mathematical values, moving from a strongly negative response "no" = 1 toward the strongly positive response "yes" $=4$. Therefore, the Spearman's Rank Correlation Test was used for the secondary data processing. A number of indicator pairs have been selected for data processing, among which the semantic coherence can be found in the meaning of their wording.

Research question: is there a correlation between the respondents' responses in accordance with these pairs of indicators (set of features)? The correlation levels were defined and interpreted in accordance with the approach accepted by the research methodology in the field of social sciences (Pelšs, 2015).

The correlation in 50 pairs of sets of features was established, that is, among the respondents' responses (assessments) in accordance with the indicator pairs. The values of the correlation coefficient were obtained within the following limits: $0.50<\left|\mathrm{r}_{\mathrm{s}}\right|<1.00$ : from moderately strong correlation to strong correlation. Table 3 summarises 7 pairs of sets of features with the following limits of correlation values obtained in the result of comparing: $0.75 \leq\left|\mathrm{r}_{\mathrm{s}}\right|<1.00$, which indicated moderately strong and strong correlation.

Table 3

\section{Correlation results between the pairs of sets of indicators: Inferential (conclusive) statistics}

$$
(n=102)
$$

\begin{tabular}{|c|c|c|c|}
\hline $\mathbf{N}$ & Pairs of sets of indicators & $\begin{array}{c}\text { Spearman's } \\
\text { Test } \\
\left(\mathbf{r}_{\mathrm{s}}\right) \\
\end{array}$ & Conclusions \\
\hline 1 & $\begin{array}{l}\text { Indicator 16. The IT company of the respondent has the methodology for the } \\
\text { evaluation of professional development available for all the specialists, which } \\
\text { is usually used during the career talks } \\
\text { Indicator 18. The methodology of the evaluation and self-evaluation of } \\
\text { professional development (its indicators) existing at the respective IT company } \\
\text { of the respondent helps the programmer in his professional self-development } \\
\text { and improvement, as well as in planning his career within the company }\end{array}$ & $\begin{array}{c}0.85 \\
\left(\left|\mathrm{r}_{\mathrm{s}}\right|>0.80\right)\end{array}$ & $\begin{array}{l}\text { There is a } \\
\text { statistically } \\
\text { significant } \\
\text { (strong) } \\
\text { correlation }\end{array}$ \\
\hline 2 & $\begin{array}{l}\text { Indicator } 2 \text {. The corporate culture of the company attaches great importance } \\
\text { to education and continuous professional development: it organises } \\
\text { continuous professional training courses, seminars, conferences, as well as it } \\
\text { has a tradition of sharing experience } \\
\text { Indicator } 3 \text {. The company has a tradition to attend various conferences, } \\
\text { seminars and other events organised outside the company, to share the } \\
\text { acquired knowledge and experience by giving presentations and } \\
\text { discussions with their colleagues }\end{array}$ & $\begin{array}{c}0.84 \\
\left(\left|\mathrm{r}_{\mathrm{s}}\right|>0.80\right)\end{array}$ & $\begin{array}{l}\text { There is a } \\
\text { statistically } \\
\text { significant } \\
\text { (strong) } \\
\text { correlation }\end{array}$ \\
\hline 3 & $\begin{array}{l}\text { Indicator } 2 \text {. The corporate culture of the company attaches great importance } \\
\text { to education and continuous professional development: it organises } \\
\text { continuous professional training courses, seminars, conferences, as well as it } \\
\text { has a tradition of sharing experience } \\
\text { Indicator } 4 \text {. New knowledge, skills and competencies obtained during the } \\
\text { continuous professional development are immediately used in the } \\
\text { professional activity of programmers and other specialists, thus promoting the } \\
\text { introduction of innovations in the IT company }\end{array}$ & $\begin{array}{c}0.84 \\
\left(\left|\mathrm{r}_{\mathrm{s}}\right|>0.80\right)\end{array}$ & $\begin{array}{l}\text { There is a } \\
\text { statistically } \\
\text { significant } \\
\text { (strong) } \\
\text { correlation }\end{array}$ \\
\hline
\end{tabular}




\begin{tabular}{|c|c|c|c|}
\hline $\mathbf{N}$ & Pairs of sets of indicators & $\begin{array}{c}\text { Spearman's } \\
\text { Test } \\
\left(r_{s}\right) \\
\end{array}$ & Conclusions \\
\hline 4 & $\begin{array}{l}\text { Indicator } 13 \text {. The company is flexible in reacting to the market demand and } \\
\text { the needs of the existing and potential clients } \\
\text { Indicator } 15 . \text { The company's specialists know the development strategy of } \\
\text { the company, its corporate objectives and tasks to be performed in the near } \\
\text { and remote future }\end{array}$ & $\begin{array}{c}0.84 \\
\left(\left|\mathrm{r}_{\mathrm{s}}\right|>0.80\right)\end{array}$ & $\begin{array}{l}\text { There is a } \\
\text { statistically } \\
\text { significant } \\
\text { (strong) } \\
\text { correlation }\end{array}$ \\
\hline 5 & $\begin{array}{l}\text { Indicator } 8 \text {. The company has experienced career growth mentors and experts } \\
\text { who regularly assess the professional growth of the employees } \\
\text { Indicator } 10 \text {. The company ensures mentoring of novice specialists during } \\
\text { their first year of employment }\end{array}$ & $\begin{array}{l}0.79 \\
\left(0.5<\left|r_{\mathrm{s}}\right|<\right. \\
0.8)\end{array}$ & $\begin{array}{l}\text { There is a } \\
\text { moderately } \\
\text { strong } \\
\text { correlation }\end{array}$ \\
\hline 6 & $\begin{array}{l}\text { Indicator } 6 \text {. The company has a well-developed mentoring system for } \\
\text { rendering support to programmers and ensuring their continuous } \\
\text { professional development. } \\
\text { Indicator } 8 \text {. The company has experienced career growth mentors and experts } \\
\text { who regularly assess the professional growth of the employees }\end{array}$ & $\begin{array}{c}0.78 \\
\left(0.5<\left|\mathrm{r}_{\mathrm{s}}\right|<\right. \\
0.8)\end{array}$ & $\begin{array}{l}\text { There is a } \\
\text { moderately } \\
\text { strong } \\
\text { correlation }\end{array}$ \\
\hline 7 & $\begin{array}{l}\text { Indicator } 2 \text {. The corporate culture of the company attaches great importance } \\
\text { to education and continuous professional development: it organises } \\
\text { continuous professional training courses, seminars, and conferences, as well } \\
\text { as it has a tradition of sharing experience } \\
\text { Indicator 10. The company ensures mentoring of novice specialists during } \\
\text { their first year of employment }\end{array}$ & $\begin{array}{l}0.75 \\
\left(0.5<\left|r_{\mathrm{s}}\right|<\right. \\
0.8)\end{array}$ & $\begin{array}{l}\text { There is a } \\
\text { moderately } \\
\text { strong } \\
\text { correlation }\end{array}$ \\
\hline
\end{tabular}

The results of the inferential (conclusive) statistics demonstrated in Table 3 give evidence of a strong correlation in 4 pairs of compared sets of indicators and allows for making the following conclusions: 1) if the IT company has a methodology for the evaluation of professional development of programmers and there are clear criteria and indicators of assessment, it helps the programmers in self-management of their professional development and career growth within this company; 2) if the corporate culture of the company attaches great importance to education and continuous professional development: it organises continuous professional training courses, seminars, conferences, as well as it has a tradition of sharing experience, then this company will also have the tradition of sharing new knowledge and experience obtained by attending various conferences, seminars organised outside the company, by making presentations and organising discussions with their colleagues; 3 ) if the IT company became a learning organization, the culture of which attaches great importance to various traditions of continuous professional development, including continuous professional training courses, then this learning IT company will be equally notable for another distinctive indicator: new knowledge, skills and competencies obtained during the continuous professional development are immediately used in the professional activity of programmers and other specialists, thus promoting the introduction of innovations in the IT company; 4) a learning IT company is able to react to the market demand, as well as to the needs of the existing and potential clients, as the IT company specialists, including programmers, have a clear understanding of the company's development strategy, its corporate objectives and tasks to be performed in the near and remote future.

\section{Conclusions}

- There are three most distinctive aspects among 19 indicators (features) of the evaluation of a learning organization in relation to the IT companies, where the research participants work: (1) a company with friendly atmosphere and mutual support, cooperation while working in a team, sharing their knowledge, skills, competencies and experience during the performance of their work duties; (2) a company is trying to ensure its sustainable development and competitiveness; (3) a company is self-educating and continuously learning to improve its activity and diversify the variety of the target groups along with a continuous improvement of its products and services.

- In its turn, the lowest results were obtained in the group of indicators that represent the information awareness of programmers about the evaluation of their professional development and its methodology within their IT companies, as well as the influence of this methodology over the self- 
management of their professional development and career growth. As a result, the following questions emerged, which should be answered within the respective companies represented by the respondents:

- have all the IT companies elaborated and use the methodology for the evaluation of the professional development of programmers?

o if such a methodology exists, are the programmers informed about its use for the evaluation of their professional development?

$\circ$ if the programmers are aware of the indicators of the methodology for the evaluation of their professional development existing in the IT company, does it help them in the management of their professional development and career growth within their IT companies, and does it help them in the preparation for the career talks with a career assessment expert/career growth mentor or a company's career counsellor?

- The obtained results testify that in general the IT companies represented by the respondents and assessed during the research correspond to the status of a learning organization.

- The results of the secondary data processing showed the correlation in 50 pairs of sets of features, that is, among the responses (assessments) given by the respondents. The correlation coefficient values were obtained within the following limits: $0.50<\left|\mathrm{r}_{\mathrm{s}}\right|<1.00$ : from moderately strong correlation to strong correlation, which confirms the correlation not only between the content of the indicator wording (semantic meaning), but also between the assessments of the research participants in accordance with the respective pairs of indicators. This implies that the assessment indicators are represented in a clear and understandable manner; 2) the respondents fairly answered the questions included in the questionnaire; 3 ) the presented assessment methodology is valid and can be used also in other researches in respect to learning IT companies.

\section{Bibliography}

1. Anjaria K. (2020). Negation and entropy: Effectual knowledge management equipment for learning organizations. Expert Systems with Applications, 157(1), 113497. doi: 10.1016/j.eswa.2020.113497

2. Antunes H., Pinheiro P. (2020). Linking knowledge management, organizational learning and memory. Journal of Innovation \& Knowledge, 5(2), 140-149. doi: 10.1016/j.jik.2019.04.002

3. Argote L., Hora M. (2017). Organizational Learning and Management of Technology. Production and Operations Management, 26(4), 579-590. doi: 10.1111/poms.12667

4. Baranova S. (2012). Augstskolu docètāju profesionālāa pilnveide tālākizglìtībāa [Professional Development of University Teachers in Continuing Education]. Promocijas darbs. Rīga: LU. Retrieved from https://dspace.lu.lv/dspace/bitstream/handle/7/4670/20541-

Sanita_Baranova_2012.pdf (in Latvian)

5. Barão A., Vasconcelos J., Rocha A., Pereira R. (2017). A knowledge management approach to capture organizational learning networks. International Journal of Information Management 37(6), 735-740. doi: 10.1016/j.ijinfomgt.2017.07.013

6. Bendickson J.S., Madden L., Matherne C.F. (2020). Graduate students mentoring undergraduate students' business innovation pitches. The International Journal of Management Education, 18(2), 100390. doi: 10.1016/j.ijme.2020.100390

7. Bologa R., Lupu A.R. (2014). Organizational learning networks that can increase the productivity of IT consulting companies. A case study for ERP consultants. Expert Systems with Applications, 41(1), 126-136. doi: 10.1016/j.eswa.2013.07.016

8. Bootz J., Monti R., Durance Ph., Pacini V., Chapuy P. (2019). The links between French school of foresight and organizational learning: An assessment of developments in the last ten years. Technological Forecasting and Social Change, 140, 92-104. doi: 10.1016/j.techfore.2018.04.007

9. Bronfenbrenner U. (1979). The ecology of human development: Experiments by nature and design. Cambridge, Mass.: Harvard University Press.

10. Bryanskiy V.P., Pozharskiy S.D. (2002). Socialnaya sinergetika $i$ akmeologiya. Teoriya samoorganizacii individuuma i sociuma [Social Synergetics and Acmeology. The Theory of Self-organization of the Individual and Society]. Sankt-Peterburg: Politehnika. (in Russian) 
11. Chen S. (2005). Task partitioning in new product development teams: A knowledge and learning perspective. Journal of Engineering and Technology Management, 22(4), 291-314. doi: 10.1016/j.jengtecman.2005.09.003

12. Cranwell-Ward J., Bossons P., Gover S. (2004). Mentoring: a Henley review of best practice. Basingstoke, Hampshire, New York: Palgrave/Macmillan.

13. Dhurup M., Surujlal J., Kabongo D.M. (2016). Finding Synergic Relationships in Teamwork, Organizational Commitment and Job Satisfaction: A Case Study of a Construction Organization in a Developing Country. Procedia Economics and Finance, 35, 485-492. doi: 10.1016/S22125671(16)00060-5

14. Drury-Grogan M.L., Conboy K., Acton T. (2017). Examining decision characteristics and challenges for agile software development. Journal of Systems and Software, 131, 248-265. doi: 10.1016/j.jss.2017.06.003

15. Garvin D.A. (1993). Building a learning organization. Harvard Business Review, 71(4), 78-91.

16. Gay G. (1995). Modeling and mentoring in urban education. Education and Urban Society, 28(1), 103-118. doi: 10.1177/0013124595028001008

17. González-Torres A., García-Peñalvo F.J., Therón-Sánchez R., Colomo-Palacios R. (2016). Knowledge discovery in software teams by means of evolutionary visual software analytics. Science of Computer Programming, 121, 55-74. doi: 10.1016/j.scico.2015.09.005

18. Haken H. (1985). Synergetics - an interdisciplinary approach to phenomena of self-organization. Geoforum, 16(2), 205-211. doi:10.1016/0016-7185(85)90029-6

19. Halpin R., Curtis P., Halpin M. (2015). Assessing Participant Performance in Online Professional Development Training Programs. Procedia Social and Behavior Sciences, 174, 186-193. doi: 10.1016/j.sbspro.2015.01.645

20. Huang L., Zhang T., Huang Y. (2020). Effects of school organizational conditions on teacher professional learning in China: The mediating role of teacher self-efficacy. Studies in Educational Evaluation, 66, 100893, 1-9. doi: 10.1016/j.stueduc.2020.100893

21. Iriste S. (2018). Prospective Managers' of Hospitality Business Competitiveness Evaluation and Development Promotion in the Dual Study Environment of Higher Education Institution. Summary of the Doctoral Thesis. Jelgava: LLU. Retrieved from https://llufb.llu.lv/dissertationsummary/pedagogics/Sandra_Iriste_prom_darba_kopsavilkums2018_LLU_IMI.pdf\#page=49

22. Judrups J. (2017). Development of Learning and Competence Management Solution. Summary of Doctoral Thesis. Jelgava: LLU, 25-56. Retrieved from https://llufb.llu.lv/dissertationsummary/information-technologies/Janis_Judrups_prom_darba_kopsavilkums_LLU_2017.pdf

23. Kačkere A., Odiņa I., Rieksta S. (2005). Mentorings Eiropāa: Latvijas perspektīva [Mentoring in Europe: Latvia's perspective]. Rīga: LR VZD Poligrāfijas daḷa "Latvijas karte". (in Latvian)

24. Katane I. (2005). The Evaluation Model of the Rural School as Educational Environment Summary of Doctoral Thesis. Daugavpils: University of Daugavpils, 35-72.

25. Katane I. (2007). Systemic ecological approach in teacher education: Ecological didactic model of students' pedagogical practice. Journal of Teacher Education for Sustainable Development, 7 , 40-54. doi: 10.2478/v10099-009-0004-7.

26. Katane I., Katans E. (2016). Programmēšanas speciālista profesionālā attīstība kā mūžilgs pašnoteikšanās un pašorganizācijas process [Programming Specialist's Professional Development as Lifelong Self-Determination and Self-Organization Process]. In V. Lubkina, S. Usca, A. Zvaigzne (Eds.), The Proceedings of the International Scientific Conference Society. Integration. Education, 2. Rezekne: Rezekne Academy of Technologies, 535-548. doi: 10.17770/sie2016vol2.1422 (in Latvian)

27. Katane I., Katans E. (2018). The Environmental Contexts of Programmer's Professional Self-Development through Learning: an Ecological and a Synergetic Approach in Research. In A. Aboltins (Ed.), Proceedings of the International Scientific Conference Engineering for Rural Development, 17. Jelgava: LLU TF, 1055-1064. doi: 10.22616/ERDev2018.17.N057

28. Katane I., Kristovska I., Katans E. (2014). Ecological perspective in analysis and evaluation of specificity of distance education environment. In V. Dislere (Ed.), The Proceedings of the International Scientific Conference Rural Environment. Education. Personality (REEP), 7. Jelgava: LLU, 66-73. Retrieved from https://lufb.llu.lv/conference/REEP/2014/Latvia-UnivAgricult-REEP-2014proceedings-66-73.pdf 
29. Katans E. (2019). Programmētāja profesionālās attīstības veicināšana mācīties spējīgā IT uzñèmumā zināšanu pārvaldības skatījumā [Promoting the Professional Development of Programmers in a Learning IT Company from the Perspective of Knowledge Management]. Mağistra darbs. Jelgava: LLU. (in Latvian)

30. Katans E., Katane I., Baltusite R. (2020). Self-Evaluation of Programmers' Competitiveness in an IT Company as Learning Organisation. In V. Dislere (Ed.), The Proceedings of the International Scientific Conference Rural Environment. Education. Personality, 13. Jelgava: Latvia University of Life Sciences and Technologies, 76-84. doi: 10.22616/REEP.2020.009

31. Kennedy M.M. (2016). How does professional development improve teaching? Review of Educational Research, 86(4), 945-980. doi: 10.3102/0034654315626800

32. Kianto A., Sáenz J., Aramburu N. (2017). Knowledge-based Human Resource Management Practices, Intellectual Capital and Innovation. Journal of Business Research, 81, 11-20. doi: 10.1016/j.jbusres.2017.07.018

33. Konstantinova E. (2008). Mentorings kā zināšanu pārneses process uzñēmējdarbības veicināšanai Latvijas laukos[Mentoring as a knowledge transfer process for business promotion in rural areas of Latvia]. Promocijas darbs. Jelgava: LLU. (in Latvian)

34. Konstantinova E., Rivža B. (2007). Mentoringa kustības rokasgrāmata [Mentoring Movement Handbook]. Jelgava: LLU. (in Latvian)

35. Krūzmētra, M. (Red.). (2006). Mentorings - inovatīvas domāšanas pārneses līdzeklis[Mentoring - a means of transferring innovative thinking). Jelgava: LLU. (in Latvian)

36. Lipowsky S. (2017). Pedagogical Means for Improvement of Self-Regulation in Self-organizing IT Group. Summary of PhD. Thesis. Riga: RPIVA, 26-52. Retrieved from https://dspace.lu.lv/dspace/bitstream/handle/7/38372/sl_kopsavilkums.pdf\#page=26

37. Lipowsky S., Schmidt J. (2016). Team Improvement and Learning in Self-Organizing Contexts. International Journal of Arts and Sciences, 9(3), 277 - 283.

http://www.universitypublications.net/ijas/0903/html/M6K396.xml

38. Mas J.M., Gomez A. (2021). Social partners in the digital ecosystem: Will business organizations, trade unions and government organizations survive the digital revolution? Technological Forecasting and Social Change, 162, 120349. doi: 10.1016/j.techfore.2020.120349

39. Masoumi D., Hatami J., Pourkaremi J. (2018). Continuing Professional Development: Policies, practices and future directions. International Journal of Educational Management, 33(1), 98-111. doi: 10.1108/IJEM-03-2018-0109

40. Mitina A. (2004). Dopolnitelnoye obrazovaniye vzroslih za rubezhom: konceptualnoye stanovleniye $i$ razvitie [Additional adult education abroad: conceptual formation and development]. Moskva: Nauka. (in Russian)

41. Pakeltienè R., Ragauskaite A. (2017). Creative Synergy as a Potential Factor for the Development of Social Innovations. In Z. Gaile (Ed.), The Proceedings of the International Scientific Conference Research for Rural Development, 2. Jelgava: LLU, 174 - 181. doi: 10.22616/rrd.23.2017.065

42. Pelšs A. (2015). Statistiskās metodes ekonomikā [Statistical methods in economics]. Rēzekne: RTA. Retrieved from http://books.rta.lv/index.php/RTA/catalog/view/15/20/64-1(in Latvian)

43. Prigozine I. (1980). From Being to Becoming. San Francisco, CA: Freeman.

44. Rozenholtz S. (1989). Teacher's Workplace: The Social Organization of Schools. New York: Longman.

45. Säljö R. (2020). Development, ageing and hybrid minds: Growth and decline, and ecologies of human functioning in a sociocultural perspective. Learning, Culture and Social Interaction, 100465. doi: 10.1016/j.lcsi.2020.100465

46. Senge P. (1990). The Fifth Discipline: The Art and Practice of the Learning Organization. New York: Doubleda.

47. Serrat O. (2017). Building a Learning Organization. In O. Serrat (Ed.), Knowledge Solutions. Singapore: Springer, 57-67.

48. Shevlokov V.A. (2016). Ustoičivoje razvitije obščestva: sinergetičeskij podhod [Sustainable Development of society: Synergetic Approach]. Vestnik KRAUNC, 2(13), 62-67. Retrieved from http://www.mathnet.ru/links/f2918d85791d5fffa0fd9a202ae1596f/vkam133.pdf (in Russian).

49. Shujahat M., Sousa M.J., Hussain S., Nawaz F., Wang M., Umer M. (2019). Translating the impact of knowledge management processes into knowledge-based innovation: The neglected and mediating 
role of knowledge-worker productivity. Journal of Business Research, 94, 442-450. doi: 10.1016/j.jbusres.2017.11.001

50. St-Germain D., Belanger L., Cote V., Gagnon C. (2020). The INSÉPArable portfolio tool to sustain continued education and the professional development of nurses for a full scope of nursing practice and enhanced patient safety competencies: An ethnographic study. International Journal of Nursing Studies Advances, 100011. doi: 10.1016/j.ijnsa.2020.100011

51. Steiner F. (2008). Human Ecology: Overview. Encyclopedia of Ecology (2 ${ }^{\text {nd }}$ ed.), 4, 336-343. doi: 10.1016/B978-0-444-63768-0.00626-0

52. Tarba Sh.Y., Ahammad M.F., Junni P., Stokes P., Morag O. (2019). The Impact of Organizational Culture Differences, Synergy Potential, and Autonomy Granted to the Acquired High-Tech Firms on the M\&A Performance. Group \& Organization Management, 44(3), 483-520. doi: $10.1177 / 1059601117703267$

53. Wang Z., Wang Z., Tahir T., Wang H., Li J., Xu G. (2020). Study of synergetic development in straw power supply chain: Straw price and government subsidy as incentive. Energy Policy, 146, 111788. doi: 10.1016/j.enpol.2020.111788

54. Yang D., Li L., Jiang X., Zhao J. (2020). The fit between market learning and organizational capabilities for management innovation. Industrial Marketing Management, 86, 223-232. doi: 10.1016/j.indmarman.2019.12.007 